\title{
Heilkenni afturkræfs æðasamdráttar í heilaæðum - ein helsta ástæða endurtekins prumuhöfuðverkjar
}

\author{
Ólafur Sveinsson læknir ${ }^{1}$ \\ Áskell Löve læknir²

\section{Vilhjálmur Vilmarsson læknir²} \\ Ingvar H. Ólafsson læknir ${ }^{3}$
}

${ }^{1}$ Taugalækningadeild, ${ }^{2}$ röntgendeild, ${ }^{3}$ taugaskurðdeild Landspítala.

Fyrirspurnum svarar Ólafur Sveinsson, olafursv@landspitali.is

\section{Inngangur}

Megineinkenni heilkennis afturkræfs æðasamdráttar í heilaæðum (Reversible cerebral vasoconstriction syndrome, RCVS) eru endurtekin prumuhöfuðverkjaköst (thunderclap headache) sem geta minnt á höfuðverk við sjálfsprottna innanskúmsblæðingu (spontaneous subarachnoid hemorrhage) en einkar mikilvægt er að greina par á milli. Í sumum tilfellum fylgja staðbundin taugaeinkenni. Æðamyndatökur geta sýnt fram á prengingu heilaæða og pað sem er mest sérkennandi er að með endurteknum rannsóknum sést að æðaherpingurinn eykst og minnkar tiltölulega hratt með tímanum. Pessar æðabreytingar ganga yfir af sjálfu sér á einum til premur mánuðum..$^{1-3}$ Pó svo að flestir sem greinast með RCVS hafi höfuðverkjaköst sem einu einkennin, verður um priðjungur fyrir heilaslagi. ${ }^{4-7}$ Öfugt við æðabreytingarnar sem ganga yfir, geta heilaslögin skilið eftir sig fötlun og jafnvel leitt til dauða.,8,9

Prátt fyrir að RCVS sé líklega algengasta ástæða endurtekins prumuhöfuðverkjar er pað aðeins á síðustu 15 árum sem sjúkdómurinn hefur verið skilgreindur og fengið nafnið RCVS. Раð er pví mikilvægt að kynna heilkennið fyrir íslenskum læknum. Snemmbær greining er mikilvæg til pess að veita rétta meðferð og forðast óparfa rannsóknir. Greiningin getur pó verið vandasöm par sem einkenni og teikn skarast við innanskúmsblæðingu og æðabólgu í miðtaugakerfinu. Í pessari grein verður fjallað um far-

\section{Á G R I P}

Heilkenni afturkræfs æðasamdráttar í heilaæðum (RCVS) einkennist af skyndilegum svæsnum höfuðverk (prumuhöfuðverk) og prengingu heilaæða, með eða án staðbundinna taugaeinkenna. Sjúkdómurinn er prefalt algengari meðal kvenna og meðalaldurinn er um 45 ár. um $60 \%$ tilfella finnst orsök, oft eftir inntöku æðavirkra efna. Pótt meingerðin sé ópekkt er almennt talið að um tímabundna vanstillingu á æðaspennu sé að ræða. Sjúkdómurinn hefur yfirleitt góðar horfur en helstu fylgikvillar eru staðbundnar innanskúmsblæðingar yfir heilaberkinum og heiladrep eða heilablæðingar sem geta haft viðvarandi fötlun í för með sér. Æ૯ðamyndataka sýnir æðaprengingar og æðavíkkanir á víxl sem ganga til baka á næstu 12 vikum. Kalsíumhemlar á borð við nímódipín minnka tíðni svæsinna höfuðverkjakasta en ekki er víst að lyfið hafi áhrif á algengi blæðinga eða heilablóðpurrðar.

aldsfræði, áhættupætti, meingerð, einkenni, greiningu og meðferð RCVS.

\section{Faraldsfræði}

Aldursdreifing sjúklinga með RCVS er mikil og hefur verið lýst hjá sjúklingum á aldrinum 13-70 ára. ${ }^{4}$ Meðalaldur er um 45 ár og sjúkdómurinn er um prefalt algengari meðal kvenna. ${ }^{4,10}$ Pannig er hinn dæmigerði sjúklingur kona á yngri fullorðinsárum. Athyglisvert er að karlmenn með RCVS eru að meðaltali 10 árum yngri við greiningu en konur. ${ }^{4}$ Nákvæmt nýgengi er ekki pekkt en fer vaxandi, líklega bæði vegna aukinnar vitundar lækna og betri æðamyndgreiningar með segulómun og tölvusneiðmyndum.

\section{Orsakir og meingerठ}

Pó að meingerðin sé ekki fyllilega pekkt er almennt talið að um tímabundna vanstillingu á æðaspennu (vascular tone) sé að ræða. ${ }^{2}$ Pessi truflun getur verið af ópekktum orsökum, en meðal pekktra orsaka er inntaka æðavirkra lyfja og nýafstaðin fæðing barns. Í um 25-60\% tilfella er hægt að finna undirliggjandi orsök. ${ }^{11}$ Á undanförnum árum hafa birst ógrynni tilfellarannsókna par sem 


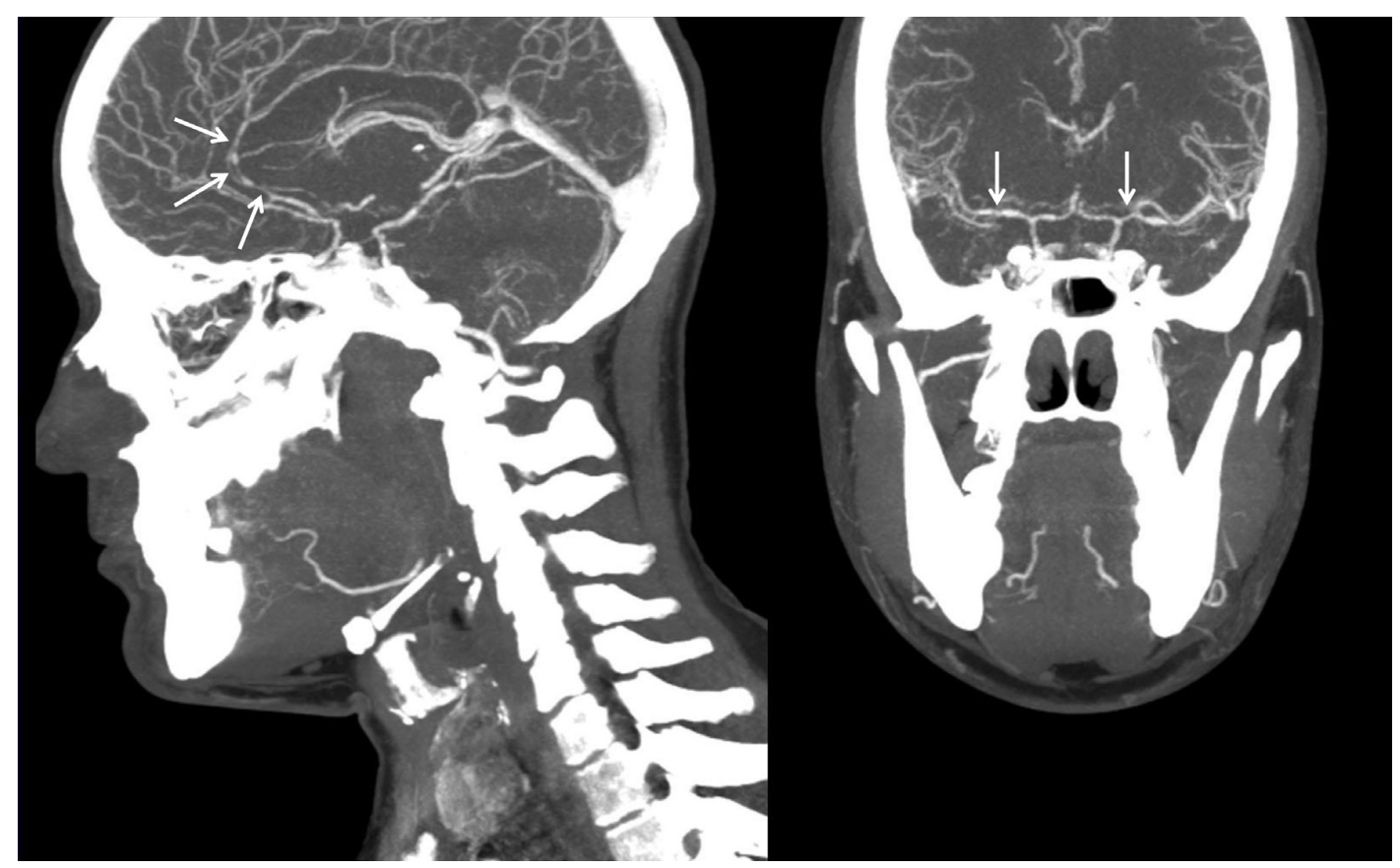

Mynd 1a. Æðamyndataka með tölvusneiðmynd (CTA) eftir inndælingu skuggaefnis í æðakerfi. Myndirnar sýna aflangar mjúkar prengingar og víkkanir á víxl í heilaslagæðum, mest áberandi i fremri hjarnaslagæðum (a. cerebri anterior) á hliðarsýn (lateral view) og í miðhjarnaslagæðum á sýn að framan (anterior view) (sjá örvar).

Mynd 1b. Eftirfylgd теð æðаmyndatöku með tölvusneiðmynd (CTA) af sama sjúklingi sem sýnir eðlilegt útlit heilaslagæða eftir að sjúkdómskastið er gengið yfir.

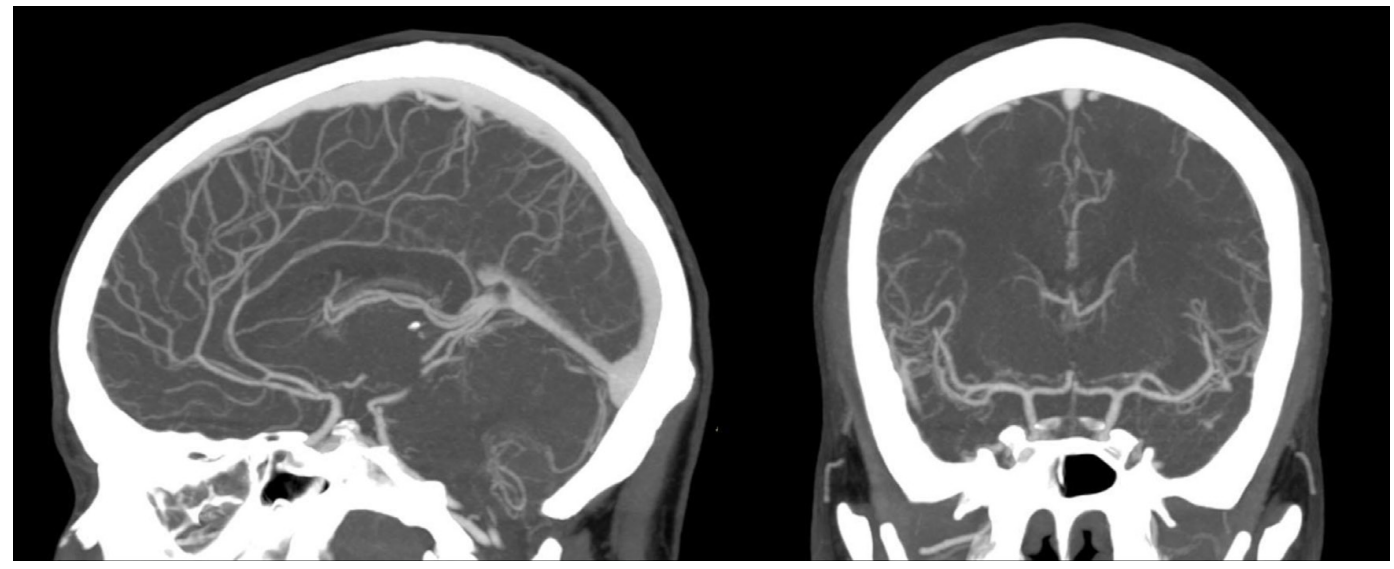

RCVS er tengt við mismunandi orsakir. Pegar lyf eru orsökin er ekki eingöngu um að ræða lyf sem sjúklingur hefur nýlega byrjað að taka heldur getur viðkomandi einstaklingur hafa tekið lyfið í langan tíma, bæði reglulega eða eftir pörfum. ${ }^{11}$ Í um 20-40\% tilfella er saga um mígreni, en óvíst er hvort mígrenisjúkdómurinn sem slíkur geti aukið áhættu á RCVS eða hvort um sé að ræða áhrif æðaherpandi mígrenilyfja (triptan-lyfja). ${ }^{12}$ Flysjun á hálsæðum hefur einnig verið tengd RCVS, en óljóst er hvort pað er orsök eða afleiðing. Í einni tilfellaseríu af RCVS höfðu 12\% samtímis flysjun á hálsæðum og í annarri tilfellaseríu af einstaklingum með flysjun í hálsæðum próuðu 7\% með sér RCVS. ${ }^{13}$ Meinafræðisýni úr fólki með RCVS hafa ekki sýnt fram á æðabólgu. ${ }^{14}$

\section{Æðavirk lyf}

Lyf sem geta valdið RCVS eru meðal annars sértækir serótónin endurupptökuhemlarar og öll örvandi $\alpha$-adrenhermandi lyf, gjarnan pau sem notuð eru til að draga úr bólgu í slímhúð nefs, vissar megrunartöflur og náttúrulyf. Óleyfileg efni á borð við kókaín og amfetamín hafa verið tengd RCVS og hafa höfundar séð nokkur slík tilfelli. Í Frakklandi er kannabis algengasta ástæðan. ${ }^{2,4}$
Eftir barnsburð

RCVS hjá konum eftir barnsburð hefst í flestum tilfellum á fyrstu premur vikunum eftir eðlilega fæðingu barns.,15 Í um 50-70\% tilfellanna hafa pó verið notuð æðaherpandi lyf, aðallega svokölluð ergot-lyf sem notuð eru til meðferðar á blæðingum eftir barnsburð, eða lyf sem koma í veg fyrir mjólkurmyndun (brómókriptín og metergín). ${ }^{9}$

\section{Klínísk einkenni}

\section{Höfuðverkur}

Endurtekinn prumuhöfuðverkur í eina til fjórar vikur ætti að vekja sterkan grun um RCVS. ${ }^{2}$ Greiningarskilmerki má sjá í töflu I. Verkurinn er yfirleitt báðum megin í höfðinu, og situr gjarnan aftarlega. Oftast er höfuðverkurinn eina einkennið (70-80\% tilfella) ${ }^{4}$ en honum getur fylgt ógleði, uppköst og ljósfælni. Sjúklingar með pekkt mígreni lýsa skyndilegri og svæsnari höfuðverk en við mígreni. Flestir lýsa vægum stöðugum höfuðverk á milli kastanna. Meirihluti sjúklinga lýsir að minnsta kosti einum útleysandi pætti: kynlífi, líkamlegri áreynslu, hósta, hnerra eða skyndilegum höfuðsnúningi. ${ }^{2,4}$ Ólíkt innanskúmsblæðingu af völdum sprungins 


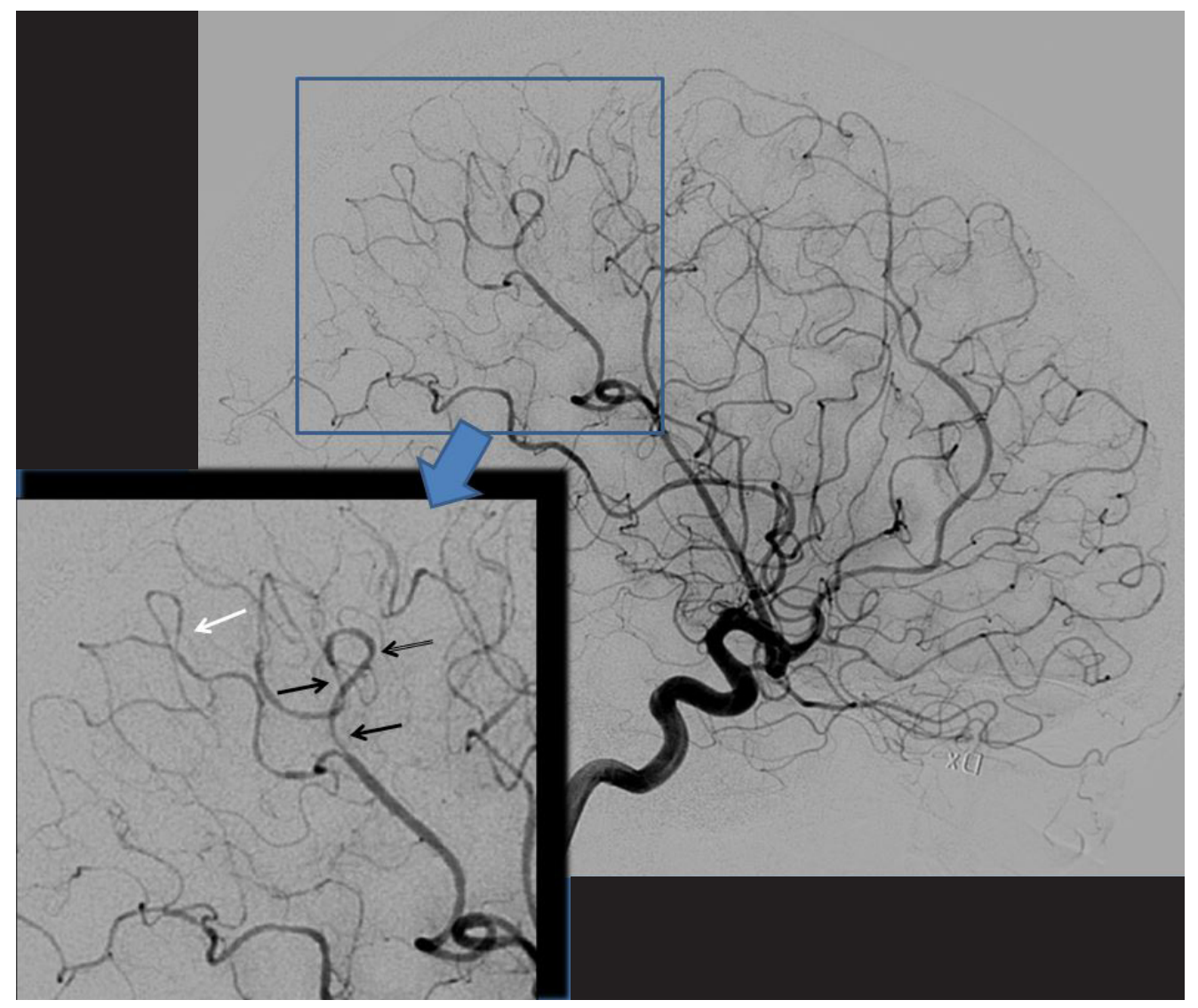

Mynd 2. Hefð̋bundin æðamyndataka eða DSA (digital subtractions angiography). Hliðarsýn (lateral view) eftir inndælingu í hálsslagæð (a. carotis interna). Á myndinni hefur jaðarsvæði mеð greinum frá mið-hjarnaslagæð (a. cerebri media) verið stækkað upp. Dar má sjá prengingar (svartar pílur) og „poststenotískar" víkkanir (píla uppi til hæori). Enn lengra í jaðr inum er grein með nánast perlulaga breytingum (hvít píla).

æðagúls hefur verkurinn í RCVS tilhneigingu til að hverfa eftir nokkrar klukkustundir (mínútur-dagar) en koma svo endurtekið í eina til prjár vikur. ${ }^{11}$ Köstin eru yfirleitt á milli 1-20 talsins. ${ }^{2}$

\section{Staðbundin taugaeinkenni eða flog}

Tíðni staðbundinna taugaeinkenna er afar breytileg eftir rannsóknum, eða á bilinu 9-63\%. ${ }^{4}$ Dæmi um slík einkenni eru máttminnkun, málstol, skert snertiskyn og sjóntruflanir. Staðbundin taugaeinkenni geta bent til undirliggjandi heiladreps eða blæðingar og leiða pessi einkenni gjarna til frekari rannsókna, svo sem æðamyndatöku. Flog eiga sér stað í 0-21\% tilfella og geta bent til undirliggjandi heilaskaða., ${ }^{2,4}$ Flog og staðbundin taugaeinkenni koma oftast fram innan 10 daga frá fyrsta höfuðverkjakastinu. ${ }^{4}$

Tafla I. Greiningarskilmerki fyrir heilkenni afturkræfs æðasamdráttar i heila. ${ }^{2}$

Skyndilegur og svæsinn höfuðverkur með eða án staðbundinna taugaeinkenna eða floga.

Einfasa (monophasic) sjúkdómsgangur án nýrra einkenna mánuði eftir upphaf einkenna.

Æðasamdráttur á heilaæðum sem sést á æðamyndum (TS-, SÓ- eða hefðbundin æðamyndataka).

Útilokun innanskúmsblæðingar vegna rofs á æðagúl.

Eðlilegur eða nánast eðlilegur mænuvökvi (prótein $<1$ g/l, hvítar frumur $<15$ / $\mathrm{mm}^{3}$ og eðlilegt magn sykurs).

ÆÆðabreytingarnar ganga til baka að öllu eđa nánast öllu leyti á endurtekinni æðamyndatöku innan 12 vikna.

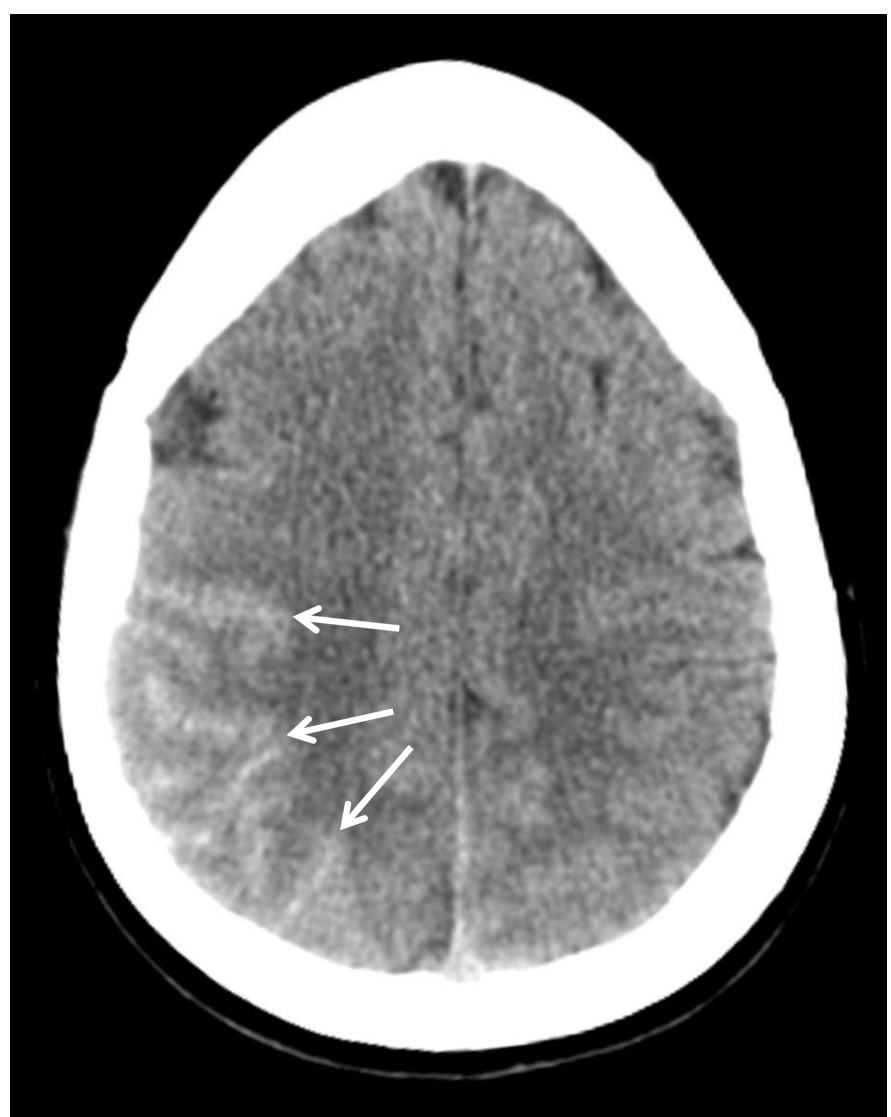

Mynd 3. Tölvusneiðmynd af höfði án skuggaefnis sýnir hápétta (hvíta) innanskúmsblæðingu í nokkrum samlægum skorum (sulci) á yfirborði hvirfilblaðs (lobus parietalis) hægra megin (sjá örvar). 


\section{Rannsóknir}

\section{Myndrannsóknir}

Tölvusneiðmynd eða segulómskoðun á höfði er oftast eðlileg en getur sýnt fram á blæðingu eða blóðpurrðarslag sem oftast er pá á vatnaskilasvæðum. Æðamyndataka getur leitt í ljós aflangar mjúkar prengingar og víkkanir (poststenotic dilatation) á víxl, sem stundum minna á perluband, í einni eða fleiri heilaæðum (mynd 1). ${ }^{2}$ Oftast eru breytingarnar pó á mörgum stöðum og mismunandi æðasvæðum. Æðarannsókn með segulómun eða tölvusneiðmynd hefur um 80\% næmi miðað við hefðbundna æðamyndatöku (mynd 2). ${ }^{4}$ Pví verður að vega og meta í hverju tilfelli fyrir sig hvort ástæða sé til hefðbundinnar æðamyndatöku í kjölfar neikvæðrar tölvusneiðmyndar. Hafa ber í huga að upphafleg æðarannsókn með tölvusneiðmynd getur verið eðlileg í allt að 20\% tilfella hjá peim sem síðan reynast vera með sjúkdóminn og pví ástæða til að endurtaka hana nokkrum dögum síðar ef klínískur grunur er sterkur. Æðaprengingar geta sést bæði í fremri og aftari blóðveitu heila og almennt eru pær dreifðar og útbreiddar. ${ }^{16}$ Endurtekin æðamyndataka nokkrum dögum síðar getur sýnt breytta dreifingu æðabreytinga, en slíkt styður að um sé að ræða RCVS frekar en æðabólgur í heilaæðum. Hálsæðaómskoðun er oftast eðlileg en Doppler-rannsókn í gegnum höfuðkúpu er gagnleg til að fylgja eftir pekktum prengingum í heilaæðum. Til að greina blæðingar, og sérstaklega heiladrep í heilavef, er segulómun mun næmari en tölvusneiðmynd., ${ }^{2,4}$ Tölvusneiðmynd eða segulómun af heila sýnir í 20-30\% tilfella fram á staðbundna innanskúmsblæðingu yfir heilaberkinum (mynd 3). Algengi heilaslags (drep eða blæðing) er breytilegt eftir rannsóknum, en er oftast á bilinu 10-30\% og getur leitt til viðvarandi fötlunar.

\section{Aðrar rannsóknir}

Mænuvökvi er yfirleitt eðlilegur í RCVS (tafla 1). Hækkun á rauðum blóðkornum getur verið til staðar við blæðingu, pó yfirleitt ekki í sama mæli og við sjálfsprottna innanskúmsblæðingu. Ef grunur er um eiturlyfjaneyslu er hægt að leita að slíkum efnum í pvagi. Ef blóðprýstingur sveiflast mjög hátt í höfuðverkjaköstum getur verið ástæða til að útiloka krómfíklaæxli (pheochromocytoma) með pví að leita að amínum í pvagi. Hefðbundnar blóðprufur (blóðhagur, sölt, lifrar- og nýrnarprufur) ásamt bólguprófum (sökk, gigtarpáttur, ANA-(antinuclear antobody) og ANCA-(antineutrophil cytoplasmic antibodies) mótefni eru venjulega neikvæð. Ekki er pörf á sýnatöku úr heilavef hjá sjúklingum með dæmigerð einkenni RCVS.

\section{Mismunagreiningar}

Við æðabólgu í heilaæðum er höfuðverkurinn yfirleitt ekki eins skyndilegur og segulómun getur bæði sýnt merki um fyrri heiladrep og mögulega upphleðslu í heilahimnum. ${ }^{17}$ Auk pess er par yfirleitt hækkun á hvítum frumum og próteinum í mænuvökva sem ekki sést í RCVS.

Blæðing vegna sprungins æðagúls er ein helsta mismunagreiningin og sú sem verður að útiloka vegna alvarleika. Yfirleitt gengur vel að skilja á milli pessara tveggja sjúkdóma. Í RCVS eru höfuðverkjaköstin endurtekin, standa yfir í styttri tíma og sjúklingur ekki eins meðtekinn. Ef meðvitundarskerðing á sér stað ætti strax að finna aðra orsök en RCVS. ${ }^{18}$ Við sjálfsprottna innanskúmsblæðingu vegna æðagúls er blæðingin venjulega meiri og útbreiðsla blóðsins önnur. Við RCVS með innanskúmsblæðingu er hún langoftast tiltölulega lítil og liggur utarlega yfir heilahvelum (mynd 3). Blæðing sem er í meira magni eða staðsett miðlægt ætti að vekja grun um brostinn æðagúl. Útlit æðaprenginga við RCVS er ekki sértækt og getur einnig sést við sjálfsprottna innanskúmsblæðingu, en par eru pær pó oftast meira miðlægt í stærri æðum og jafnari. ${ }^{19}$

\section{Meðferð}

Meðferðin er fyrst og fremst við einkennum. Verkjalyf eru notuð við höfuðverk og flogaveikilyf við flogum. Æskilegt er að fylgjast náið með blóðprýstingi, tryggja gott vökvaástand og sjá til pess að sjúklingar hvíli sig í bráđafasanum á meðan prumuhöfuðverkjaköst ganga yfir. Ekki er mælt með kynlífi eða líkamlegri áreynslu fyrstu tvær vikurnar eftir köstin. Loks er mikilvægt að spyrja sjúklinginn náið út í notkun æðavirkra lyfja og hætta notkun peirra pegar í stað. Forðast ber notkun triptan-lyfja og annarra æðaherpandi lyfja. ${ }^{8}$ Pó að slembiraðaðar rannsóknir um gagnsemi liggi ekki fyrir, er meðferð með kalsíumhemlaranum nímódipín yfirleitt hafin. ${ }^{2}$ Hægt er að gefa lyfið í æð í sömu skömmtum og við innanskúmsblæðingu, en pað er oftar gefið á töfluformi, 60 mg prisvar til 6 sinnum á dag, í tvær til 12 vikur. Áhrifin virðast fyrst og fremst vera á hin svæsnu prumuhöfuðverkjaköst sem stöðvast venjulega innan nokkurra daga. Aftur á móti er ekki víst að lyfið minnki áhættuna á heilablóðpurrð eða blæðingu. ${ }^{4}$ Hjá sjúklingum sem hafa fyrir lágan blóðprýsting parf að fara varlega með skömmtun lyfsins til pess að auka ekki líkur á heilablóðpurrð. Áður en RCVS-heilkennið varð vel skilgreint voru barksterar oft gefnir vegna gruns um æðabólgu. Í dag er notkun peirra ekki talin ráðleg og hugsanlega geta peir haft skaðleg áhrif. ${ }^{20}$ Engin rök liggja fyrir að nota blóðflöguhemjandi eða kólesteróllækkandi meðferð í RCVS.

\section{Horfur}

Horfur eru yfirleitt góðar og hægt að reikna með að flestir nái sér að fullu. Fyrir pann minnihluta sjúklinga sem hlotið hafa heilaslag af völdum æðabreytinganna geta pær skilið eftir sig mismikla fötlun., Einstaka sjúklingar hafa látist af völdum sjúkdómsins, helst pá konur eftir barnsburð. ${ }^{9}$ Eftir bráðafasann hefur um priðjungur sjúklinganna vægan viðvarandi höfuðverk, oft með meðfylgjandi preytu. Sjaldgæft (5\%) er að RCVS taki sig upp aftur. ${ }^{10,11,22}$

\section{Samantekt}

Endurtekin prumuhöfuðverkur yfir nokkurra daga tímabil ætti að vekja sterkan grun um RCVS. Greininguna er pó ekki fyllilega hægt að staðfesta fyrr en eftir að æðabreytingarnar hafa gengið til baka innan 12 vikna. ${ }^{4}$ Kalsíumhemlar á borð við nímódipín minnka tíðni prumuhöfuðverkjar. 


\section{Heimildir}

1. The International Classification of Headache Disorders. Cephalalgia 2004; 24: 1-160.

2. Calabrese LH, Dodick DW, Schwedt TJ, Singhal AB. Narrative review: reversible cerebral vasoconstriction syndromes. Ann Intern Med 2007; 146: 34-44.

3. Stefánsdóttir A, Löve Á, Práinsdóttir SG, Lúđvígsson P. Brátt blóðpurrðarslag hjá unglingsstúlku. Sjúkratilfelli. Læknablaðið 2015; 101: 363-6

4. Ducros A, Boukobza M, Porcher R, Sarov M, Valade D, Bousser MG. The clinical and radiological spectrum of reversible cerebral vasoconstriction syndrome. A prospective series of 67 patients. Brain 2007; 130: 3091-101.

5. Edlow BL, Kasner SE, Hurst RW, Weigele JB, Levine JM. Reversible cerebral vasoconstriction syndrome associated with subarachnoid hemorrhage. Neurocrit Care 2007; 7 203-10.

6. Moskowitz SI, Calabrese LH, Weil RJ. Benign angiopathy of the central nervous system presenting with intracerebral hemorrhage. Surg Neurol 2007; 67: 522-7.

7. Chen SP, Fuh JL, Chang FC, Lirng JF, Shia BC, Wang SJ Transcranial color doppler study for reversible cerebral vasoconstriction syndromes. Ann Neurol 2008; 63: 751-7.

8. Singhal AB, Caviness VS, Begleiter AF, Mark EJ, Rordorf G, Korohetz WJ. Cerebral vasoconstriction and stroke after use of serotonergic drugs. Neurology 2002; 58: 130-3.
9. Williams TL, Lukovits TG, Harris BT, Harker Rhodes C. A fatal case of postpartum cerebral angiopathy with literature review. Arch Gynecol Obstet 2007; 275: 67-77.

10. Miller TR, Shivashankar R, Mossa-Basha M, Gandhi D. Reversible Cerebral Vasoconstriction Syndrome, Part 1: Epidemiology, Pathogenesis, and Clinical Course. AJNR Am J Neuroradiol 2015; 36: 1392-9.

11. Ducros A, Bousser MG. Reversible cerebral vasoconstriction syndrome. Pract Neurol 2009; 9: 256-67.

12. Singhal AB, Hajj-Ali RA, Topcuoglu MA, Fok J, Bena $\mathrm{J}$, Yang $\mathrm{D}$, et al. Reversible cerebral vasoconstriction syndromes: analysis of 139 cases. Arch Neurol 2011; 68: 1005-12.

13. Mawet J, Boukobza M, Franc J, Saroy M, Arnold M, Bousser MG, et al. Reversible cerebral vasoconstriction syndrome and cervical artery dissection in 20 patients. Neurology 2013; 81: 821-4

14. de Boysson H, Parienti JJ, Mawet J, Arquizan C, Boulouis G, Burcin C, et al. Primary angiitis of the CNS and reversible cerebral vasoconstriction syndrome: A comparative study. Neurology 2018; 91: 1468-78.

15. Singhal AB. Cerebral vasoconstriction syndromes. Top Stroke Rehabil 2004; 11: 1-6.
16. Dodick DW, Brown RD, Britton JW, Huston J. Nonaneurysmal thunderclap headache with diffuse, multifocal, segmental, and reversible vasospasm. Cephalalgia 1999; 19: 118-23.

17. Singhal AB, Topcuoglu MA, Fok JW, Kursun O, Noqueira RG, Frosch MP, et al. Reversible cerebral vasoconstriction syndromes and primary angiitis of the central nervous system: clinical, imaging, and angiographic comparison. Ann Neurol 2016; 79: 882.

18. Sveinsson O, Ólafsson $\mathrm{IH}$, Kjartansson Ó, Valdimarsson EM. Sjálfsprottin innanskúmsblæðing - yfirlitsgrein. Læknablaðið 2013; 99: 391-7.

19. Muehlschlegel S, Kursun O, Topcuoglu MA, Fok J, Singhal AB. Differentiating reversible cerebral vasoconstriction syndrome with subarachnoid hemorrhage from other causes of subarachnoid hemorrhage. JAMA Neurol 2013; 70: 1254 .

20. Singhal AB, Topcuoglu MA. Glucocorticoid-associated worsening in reversible cerebral vasoconstriction syndrome. Neurology 2017; 88: 228.

21. Ducros A. Reversible cerebral vasoconstriction syndrome. Handb Clin Neurol 2014; 121: 1725-41.

22. Chen SP, Fuh JL, Lirng JF, Wang YF, Wang SJ. Recurrence of reversible cerebral vasoconstriction syndrome: a longterm follow-up study. Neurology 2015; 84: 1552-8.

\section{Reversible cerebral vasoconstriction syndrome - a common cause of thunderclap headache}

\author{
Ólafur Sveinsson ${ }^{1}$ \\ Áskell Löve ${ }^{2}$ \\ Vilhjálmur Vilmarsson ${ }^{2}$ \\ Ingvar Ólafsson ${ }^{3}$
}

Reversible cerebral vasoconstriction is characterized by thunderclap headache and vasoconstriction of cerebral arteries, with or without focal neurologic symptoms.

The syndrome is three times more common in women with a mean age around 45 years. In approximately $60 \%$ of cases a cause can be identified, commonly after intake of vasoactive substances. The pathophysiology of reversible cerebral vasoconstriction syndrome is unknown, though temporary dysregulation in cerebral vascular tone is thought to be a key underlying mechanism. The syndrome typically follows a ben- ign course; however, complications such as ischemic stroke or intracranial hemorrhage can cause permanent disability or death in a small minority of patients. Vascular imaging reveals alternating cerebral vasoconstriction and vasodilation that normalizes within 12 weeks. Calcium channel antagonists such as nimodipine reduce the frequency of thunderclap headaches but do not decidedly affect the risk of cerebral ischemia or hemorrhage. In this article the epidemiology, risk factors, pathophysiology, symptoms, diagnosis and treatment of RCVS is reviewed.

'Department of Neurology, University Hospital of Iceland, ${ }^{2}$ Department of Radiology, University Hospital of Iceland, ${ }^{3}$ Department of Neurosurgery, University Hospital of Iceland, Reykjavik, Iceland.

Key words: reversible cerebral vasoconstriction syndrome, RCVS, cerebral infarction, intracranial hemorrhage, thunderclap headache.

Correspondence: Ólafur Sveinsson, olafursv@landspitali.is 